\title{
Nitrogen Critical Loads for an Alpine Meadow Ecosystem on the Tibetan Plateau
}

\author{
Ning Zong ${ }^{1,3} \cdot$ Peili Shi $^{1} \cdot$ Minghua Song ${ }^{2} \cdot$ Xianzhou Zhang ${ }^{1} \cdot$ Jing Jiang $^{4} \cdot$ \\ Xi Chai ${ }^{1,3}$
}

Received: 12 April 2015/Accepted: 29 September 2015/Published online: 16 October 2015

(C) Springer Science+Business Media New York 2015

\begin{abstract}
Increasing atmospheric nitrogen $(\mathrm{N})$ deposition has the potential to alter plant diversity and thus the function and stability of terrestrial ecosystems. N-limited alpine ecosystems are expected to be particularly susceptible to increasing $\mathrm{N}$ deposition. However, little is known about the critical loads and saturation thresholds of ecosystem responses to increasing $\mathrm{N}$ deposition on the Tibetan Plateau, despite its importance to ecosystem management. To evaluate the $\mathrm{N}$ critical loads and $\mathrm{N}$ saturation thresholds in an alpine ecosystem, in 2010, we treated an alpine meadow with five levels of $\mathrm{N}$ addition $\left(0,10,20,40\right.$, and $80 \mathrm{~kg} \mathrm{~N} \mathrm{ha}^{-1}$ year $\left.^{-1}\right)$ and characterized plant and soil responses. The results showed that plant species richness and diversity index did not statistically vary with $\mathrm{N}$ addition treatments, but they both
\end{abstract}

Electronic supplementary material The online version of this article (doi:10.1007/s00267-015-0626-6) contains supplementary material, which is available to authorized users.

Peili Shi

shipl@igsnrr.ac.cn

1 Lhasa National Ecological Research Station, Key Laboratory of Ecosystem Network Observation and Modelling, Institute of Geographic Sciences and Natural Resources Research, Chinese Academy of Sciences, 11A, Datun Road, Chaoyang District, Beijing 100101, China

2 Key Laboratory of Ecosystem Network Observation and Modelling, Institute of Geographic Sciences and Natural Resources Research, Chinese Academy of Sciences, Beijing 100101, China

3 University of Chinese Academy of Sciences, Beijing 100049, China

4 Nanjing Agricultural Institute of Jiangsu Hilly Region, Nanjing 210046, Jiangsu, China changed with years. $\mathrm{N}$ addition affected plant cover and aboveground productivity, especially for grasses, and soil chemical features. The $\mathrm{N}$ critical loads and saturation thresholds, in terms of plant cover and biomass change at the community level, were $8.8-12.7$ and $50 \mathrm{~kg} \mathrm{~N} \mathrm{ha}^{-1}$ year $^{-1}$ (including the ambient $\mathrm{N}$ deposition rate), respectively. However, pronounced changes in soil inorganic $\mathrm{N}$ and net $\mathrm{N}$ mineralization occurred under the 20 and $40 \mathrm{~kg} \mathrm{~N} \mathrm{ha}^{-1}$ year $^{-1}$ treatments. Our results indicate that plant community cover and biomass are more sensitive than soil to increasing $\mathrm{N}$ inputs. The plant community composition in alpine ecosystems on the Qinghai-Tibetan Plateau may change under increasing $\mathrm{N}$ deposition in the future.

Keywords Alpine meadow - Nitrogen critical loads . Nitrogen deposition - Plant community composition . Qinghai-Tibetan Plateau $\cdot$ Soil characteristics

\section{Introduction}

Human activities in the last century have resulted in a pronounced increase in atmospheric nitrogen $(\mathrm{N})$ deposition around the world (Galloway et al. 2004, 2008). Increasing $\mathrm{N}$ deposition has reached a level that dramatically influences the stability of some natural ecosystems (Matson et al. 2002). For example, plant communities would shift under increasing $\mathrm{N}$ deposition (Bobbink et al. 1998; Bragazza et al. 2004; Sala et al. 2000), and such shifts are generally associated with a decline in plant species richness and a loss of biodiversity (Bobbink et al. 2010; Stevens et al. 2004, 2010). Additionally, some soil processes, especially the soil $\mathrm{N}$ cycle, can be altered by $\mathrm{N}$ enrichment ( $\mathrm{Lu}$ et al. 2011). 
Although external $\mathrm{N}$ input generally increases aboveground net primary production by alleviating ecosystem $\mathrm{N}$ limitation (LeBauer and Treseder 2008; Xia and Wan 2008), N enrichment may decrease plant species richness by shifting plant communities toward compositions that have the ability to acquire and/or tolerate high $\mathrm{N}$ levels (Bowman et al. 2008). Such losses in species diversity, in turn, will affect ecosystem productivity and stability (Bai et al. 2004; Tilman et al. 1996, 2006). In addition, continuous high levels of $\mathrm{N}$ enrichment can substantially change soil physical and chemical characteristics by decreasing soil pH (Guo et al. 2010; Phoenix et al. 2012), which leads to increases in hydrogen $\left(\mathrm{H}^{+}\right)$and aluminum $\left(\mathrm{Al}^{3+}\right)$ ions, as well as calcium $\left(\mathrm{Ca}^{2+}\right)$ and magnesium $\left(\mathrm{Mg}^{2+}\right)$ leaching (Stevens et al. 2010). These deleterious changes in soil properties may further reduce plant diversity and productivity (Stevens et al. 2010). More importantly, some soil processes themselves can serve as "N-saturation" signals of ecosystem responses to $\mathrm{N}$ enrichment (Bowman et al. 2006; Lieb et al. 2011). For example, significant increases in nitrate $\left(\mathrm{NO}_{3}{ }^{-}-\mathrm{N}\right)$ as $\mathrm{N}$ leaching, soil solution inorganic $\mathrm{NO}_{3}{ }^{-}-\mathrm{N}$, and net $\mathrm{N}$ nitrification have occurred at $\mathrm{N}$ deposition rates above $20 \mathrm{~kg} \mathrm{~N} \mathrm{ha}^{-1}$ year $^{-1}$ in alpine dry meadows of the Colorado Rocky Mountains (Bowman et al. 2006). Taken together, these plant community and soil properties can be regarded as sensitive indicators of ecosystem responses to increasing $\mathrm{N}$ deposition, as well as $\mathrm{N}$ "critical loads" (Bobbink and Roelofs 1995; Bowman et al. 2006; Bragazza et al. 2004).

Critical loads, which have been widely used by environmentalists to assess the impacts of pollutants on ecosystems, are generally defined as the minimum input of a pollutant that causes a significant "harmful effect" on a sensitive ecological indicator (Bobbink and Roelofs 1995; Bowman et al. 2006, 2012; Porter et al. 2005). The $\mathrm{N}$ critical load for changes in vegetation is defined as the $\mathrm{N}$ input level below which no biotic change (such as plant cover, biomass, or species composition) would occur (Bowman et al. 2006). N saturation is defined by Aber et al. (1989) as the point when ammonium and nitrate availability exceed plant and microbial nitrogen demand. Indicators of $\mathrm{N}$ saturation have been documented by soil-based measures, including changes in $\mathrm{N}$ mineralization, nitrification, and $\mathrm{NO}_{3}{ }^{-}-\mathrm{N}$ leaching rates (Aber et al. 1989; Bowman et al. 2006; Lovett and Goodale 2011; Pardo et al. 2011), or changes in sensitive biota, such as plant community composition (Bowman et al. 2006, 2012; Lovett and Goodale 2011). Previous studies showed that plant diversity and soil characteristics would respond nonlinearly to multi-level $\mathrm{N}$ additions (Wei et al. 2013). Hence, multilevel $\mathrm{N}$ addition experiments (Bai et al. 2010; Bowman et al. 2006; 2012) are important tools for the estimation of $\mathrm{N}$ critical loads of ecosystems.

The Qinghai-Tibetan Plateau, known as "the roof of the world" and "the Earth's third pole," is the birthplace of the great rivers in China and other Asian countries (Zheng et al. 1979; Sun et al. 2012). The alpine ecosystem is very fragile and sensitive to climatic changes, and it may act as an "indicator region" for environmental changes (Tang et al. 1986). Although atmospheric $\mathrm{N}$ deposition is very dramatic on the eastern Qinghai-Tibetan Plateau region, ranging from 8.7 to $13.8 \mathrm{~kg} \mathrm{~N} \mathrm{ha}^{-1}$ year $^{-1}$ (Lü and Tian 2007), and to date, no estimations of $\mathrm{N}$ critical loads and saturation thresholds in response to increasing $\mathrm{N}$ deposition have been reported in alpine ecosystems on the QinghaiTibetan Plateau. Because of their thin soils and low biological buffering capacity, alpine ecosystems are particularly susceptible to continued $\mathrm{N}$ deposition (Williams et al. 1996; Williams and Tonnessen 2000; Bowman et al. 2006). If $\mathrm{N}$ input thresholds are reached and/or exceeded, national water resources and ecological security will be endangered. Here, we used a multi-level $\mathrm{N}$ addition experiment to determine the $\mathrm{N}$ critical loads for plants and soils in an alpine meadow in the heartland of the Qinghai-Tibetan Plateau; more specifically, we studied changes in plant composition and biomass, soil inorganic $\mathrm{N}$, mineralization, and microbial biomass.

\section{Materials and Methods}

\section{Site Description and Experimental Design}

The study was performed in an alpine meadow community approximately $3 \mathrm{~km}$ north of Damxung County, Tibet Autonomous Region, China $\left(91^{\circ} 05^{\prime} \mathrm{E}, 30^{\circ} 51^{\prime} \mathrm{N}\right)$. The site is located on the south-facing slope of the Nyainqentanglha Mountains at 4,333 $\mathrm{m}$ above sea level in the mid-south of the Tibetan Plateau. A detailed description of the experimental site can be found in Jiang et al. (2013). The climate in this site is characterized as the semi-arid continental type. The mean annual temperature is $1.3{ }^{\circ} \mathrm{C}$, with a minimum of $-10.4{ }^{\circ} \mathrm{C}$ in January and a maximum of $10.7{ }^{\circ} \mathrm{C}$ in July. Annual precipitation is $477 \mathrm{~mm}, 85 \%$ of which falls from June to August. The soil is classified as Mat-Gryic Cambisol, corresponding to Gelic Cambisol, with a depth of approximately $0.3-0.5 \mathrm{~m}$. The soil particle composition is $67.02 \%$ sand, $18.24 \%$ silt, and $14.74 \%$ clay (Fu et al. 2012). Detailed soil properties can be found in the study by Zong et al. (2014a, b). The alpine meadow is dominated by the sedges Kobresia pygmaea C.B. Clarke var. pygmaea and Carex montis-everestii, and the grass Stipa capillacea Keng. In addition, the meadow has also 
been invaded by the forb Anaphalis xylorhiza due to degradation resulting from overgrazing. The total atmospheric inorganic $\mathrm{N}$ deposition at the study site is approximately $6.0 \mathrm{~kg} \mathrm{~N}^{-1}$ year $^{-1}$ (unpublished data), as estimated from wet deposition measurements by an ion exchange resin collector.

A complete randomized block design was used for $\mathrm{N}$ deposition manipulation. Four blocks were established, and five $3 \mathrm{~m} \times 3 \mathrm{~m}$ split plots were established in each block, with 2-m aisles as buffering zones between the adjacent plots. The experimental treatments consisted of four levels of $\mathrm{N}$ fertilization $\left(10,20,40\right.$, and $80 \mathrm{~kg} \mathrm{~N}^{-1}$ year $^{-1}$ ), which were roughly 1.5-, 3-, 6-, and 12-fold greater than the ambient $\mathrm{N}$ deposition in Damxung County, along with a control treatment. $\mathrm{N}$ was applied three times during the growing season as $\mathrm{NH}_{4} \mathrm{NO}_{3}$ in an aqueous solution (9 L per plot) using sprayers. Half the dose of the nitrogenous fertilizer was applied in mid-May at the beginning of seedling establishment, and the remaining half was applied in two treatments, one in early June and another in early August. The amount of water added to the plots equaled a 6-mm increase in precipitation (approximately a $1.2 \%$ increase in annual precipitation), which was well within the range of inter-annual variability (20.3\% from 1981 to 2010; data were obtained from the Damxung meteorological station). The plots were established in 2010, and the $\mathrm{N}$ fertilizer was applied annually from 2010 to 2013 .

\section{Field Survey and Plant Sampling}

The plant community composition within the plots was measured yearly from 2011 to 2013 (except for the $80 \mathrm{~kg} \mathrm{~N} \mathrm{ha}^{-1}$ year $^{-1}$ addition treatment in 2011). The mean cover of each plant species was measured during the peak growing season, which occurred in mid-August, using a $50 \mathrm{~cm} \times 50 \mathrm{~cm}$ quadrat divided into $2510 \mathrm{~cm} \times 10 \mathrm{~cm}$ sub-squares in each plot (Lin et al. 2011; Wang et al. 2012a). Species richness and the Shannon-Wiener diversity index $\left(H^{\prime}\right)$, which represents both the richness and evenness of species, were calculated annually for each plot.

To examine the response of the aboveground production of each plant functional group to the $\mathrm{N}$ addition treatments, aboveground biomass was clipped in the $50 \mathrm{~cm} \times 50 \mathrm{~cm}$ sub-squares after field surveying within each of the plots. Biomass was clipped annually during the peak growing season in mid-August (except for the $80 \mathrm{~kg} \mathrm{~N} \mathrm{ha}^{-1}$ year $^{-1}$ addition treatment in 2011). The plants were separated into four functional groups, including grasses ( $S$. capillacea and Poa spp.), sedges (Kobresia spp. and Carex spp.), Anaphalis xylorhiza, and all other forbs. After harvesting, the biomass of each functional group was oven dried at $65^{\circ} \mathrm{C}$ for $48 \mathrm{~h}$ and weighed. The dry matter weight was measured $( \pm 0.01 \mathrm{~g})$ and calculated on a per square meter basis.

\section{Soil Sampling and Laboratory Analysis}

Five soil cores were randomly sampled in each quadrat using an auger $(3.8 \mathrm{~cm}$ in diameter, $15 \mathrm{~cm}$ in depth) after collection of the plant aboveground materials in each growing season (except for the $80 \mathrm{~kg} \mathrm{~N} \mathrm{ha}^{-1}$ year $^{-1}$ addition treatment in 2011). The five cores were mixed as a composite soil sample and immediately passed through a $2-\mathrm{mm}$ sieve to remove roots, gravel, and stones. Within $48 \mathrm{~h}, \mathrm{NO}_{3}{ }^{-}-\mathrm{N}$ and ammonium as nitrogen $\left(\mathrm{NH}_{4}{ }^{+}-\mathrm{N}\right)$ in the composite soil

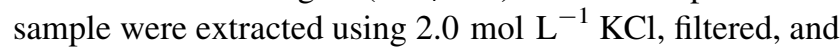
analyzed on a continuous flow analyzer (AA3, SEAL Analytical, Norderstedt, Germany).

Soil microbial biomass carbon (SMC) and N (SMN) were measured using the chloroform fumigation extraction method (Fu et al. 2012; Vance et al. 1987). Briefly, fumigated and unfumigated soil samples were extracted with $0.5 \mathrm{~mol} \mathrm{~L}{ }^{-1}$ potassium sulfate $\left(\mathrm{K}_{2} \mathrm{SO}_{4}\right)$ and filtered through a $0.45-\mu \mathrm{m}$ filter membrane. The levels of extractable organic $\mathrm{C}$ and $\mathrm{N}$ were determined by a liquiTOC II analyzer (Elementar Co., Hanau, Germany) and by potassium persulfate $\left(\mathrm{K}_{2} \mathrm{~S}_{2} \mathrm{O}_{8}\right)$ oxidation as measured by a UV-1700 PharmaSpec UV-Vis spectrophotometer (Shimadzu, Kyoto, Japan), respectively. The extractable $\mathrm{C}$ and $\mathrm{N}$ were converted to SMC and SMN using conversion coefficients of $0.45(\mathrm{Fu}$ et al. 2012; Xu et al. 2010).

The soil net $\mathrm{N}$ mineralization rate $\left(R_{\min }\right)$ was measured using the buried soil core technique (Contosta et al. 2011; Zong et al. 2013). The concentrations of extractable $\mathrm{NO}_{3}{ }^{-}-$ $\mathrm{N}$ and $\mathrm{NH}_{4}{ }^{+}-\mathrm{N}$ were compared in initial and incubated soil cores in situ for approximately 3 weeks from early to late August and then divided by incubation time to obtain the net ammonification and nitrification rates $\left(\mathrm{mg} \mathrm{kg}^{-1} \mathrm{~d}^{-1}\right)$.

\section{Data Analysis}

The response function for the change in vegetation cover per year versus the $\mathrm{N}$ deposition rate was estimated using a polynomial dose response curve, with the $x$-intercept providing the $\mathrm{N}$ critical load for vegetation change (Bowman et al. 2006, 2012). We estimated the $\mathrm{N}$ critical load for changes in vegetation cover or biomass as the $\mathrm{N}$ deposition rate below which no significant increase in cover or biomass of each functional group would occur, while above which the cover or biomass of vegetation increased. The vegetation community data (species richness, diversity, cover, and biomass) were analyzed using two-way ( $\mathrm{N}$ addition levels and experimental years) analysis of variance (ANOVA). One-way ANOVA followed by Tukey's multiple comparisons was used to examine the effects of $\mathrm{N}$ addition on cover, the biomass in each functional group and the total community, the soil inorganic $\mathrm{N}$ concentration, net $R_{\text {min }}$ (including nitrification and ammonification), SMC, and SMN in each 
experimental year. Before each analysis, all data were tested for homogeneity. Heterogeneous data were ln-transformed before analysis. The significance level was the $95 \%$ confidence interval. All the analyses were performed in SPSS 16.0 (SPSS for Windows, Version 16.0, Chicago, IL, USA).

\section{Results}

\section{Vegetation Responses: Plant Community Composition and Biomass}

Plant species numbers in the manipulated plots ranged from 10 to 14. Neither species richness (Fig. 1a) nor the Shannon-Wiener diversity index $\left(H^{\prime}\right)$ (Fig. $\left.1 \mathrm{~b}\right)$ varied with $\mathrm{N}$ addition treatments (Fig. 1; Table 1), while they both changed with years. There were no interactive effects of treatment and year on species richness and $H^{\prime}$ (Table 1).

The effects of $\mathrm{N}$ addition on community cover were significant and increased with experimental years (Fig. 2, $P=0.039$ in 2011, $P=0.024$ in 2012, and $P<0.001$ in 2013). In the second (2011) and third (2012) years, the effects of $\mathrm{N}$ treatments on community cover were only significant under the $40 \mathrm{~kg} \mathrm{~N} \mathrm{ha}^{-1}$ year $^{-1}$ addition treatment (Fig. 2a, b), while in the fourth year (2013), the effects were significant for all the $\mathrm{N}$ addition treatments (Fig. 2c). There were declining trends in community cover in the $80 \mathrm{~kg} \mathrm{~N} \mathrm{ha}^{-1}$ year $^{-1}$ addition treatment, primarily due to $\mathrm{N}$ saturation at this high $\mathrm{N}$ addition level (Fig. 2b, c).

In the control plots, the cover of grasses, sedges, Anaphalis xylorhiza, and all other forbs were 7.35-9.13, 8.3-14.62, 7.33-14.33, and 7.50-12.43\%, respectively. The only functional group that responded significantly to the $\mathrm{N}$ addition treatments was the grasses, which increased depending on the $\mathrm{N}$ levels $(P<0.01$ during all three years, Fig. 2; Table 1). For example, the average cover of grasses increased by $115,133,224$, and $108 \%$ in the $10,20,40$, and $80 \mathrm{~kg} \mathrm{~N} \mathrm{ha}^{-1}$ year $^{-1}$ addition treatments in 2013 , respectively (Fig. 2). The cover of sedges and Anaphalis xylorhiza showed no significant responses to the $\mathrm{N}$ addition treatments, while other forbs showed inter-annual variations, with significant increases in 2011 and 2013, and insignificant changes in 2012 (Fig. 2).

As the vegetation cover of plant functional groups exhibited a declining trend when the $\mathrm{N}$ addition rate reached $40 \mathrm{~kg} \mathrm{~N} \mathrm{ha}^{-1}$ year $^{-1}$, $\mathrm{N}$ critical loads for vegetation changes were 9.2 and $12.7 \mathrm{~kg} \mathrm{~N} \mathrm{ha}^{-1}$ year $^{-1}$ (including ambient deposition) for grasses and forbs, respectively. Furthermore, we inferred the $\mathrm{N}$ input threshold for the plant community in this alpine meadow to be approximately $50 \mathrm{~kg} \mathrm{~N} \mathrm{ha}^{-1}$ year $^{-1}$ (Fig. 3).

The total aboveground biomass increased significantly under the $\mathrm{N}$ addition treatments from the second to the fourth experimental year. In 2011 and 2013, the increase in aboveground biomass was pronounced when the $\mathrm{N}$ addition rate was greater than $20 \mathrm{~kg} \mathrm{~N} \mathrm{ha}^{-1}$ year $^{-1}$ (Fig. 4a, c), while in 2012, plant aboveground biomass increased significantly by $40.3,51.2,84.8$, and $68.8 \%$ under the 10,20 , 40 , and $80 \mathrm{~kg} \mathrm{~N} \mathrm{ha}^{-1}$ year $^{-1}$ addition treatments, respectively (Fig. 4b). Total aboveground biomass exhibited declining trends under the $80 \mathrm{~kg} \mathrm{~N} \mathrm{ha}^{-1}$ year $^{-1}$ addition treatment (Fig. 4b, c).

In the control plots, the biomass proportions of grasses, sedges, Anaphalis xylorhiza, and all other forbs were 10.1$17.2,14.5-23.9,38.8-52.1$, and 20.1-22.7 \%, respectively. Similar to the plant cover response, the functional group that was most sensitive to the $\mathrm{N}$ addition treatments was grasses (Fig. $4, P<0.001$ ). In addition, the aboveground biomass of forbs was also enhanced by $\mathrm{N}$ enrichment, and the response increased over time (Fig. $4, P=0.017$ in 2011, $P=0.015$ in 2012, and $P<0.001$ in 2013). The aboveground biomass response for sedges and Anaphalis xylorhiza varied with years, with a decline of sedges in 2011 and no significant changes in 2012 and 2013 (Fig. 4).

We also estimated the $\mathrm{N}$ critical load above which the biomass of each functional group changed. Similar to plant cover, the biomass of grasses exhibited a declining trend when the $\mathrm{N}$ addition rate was greater than
Fig. 1 Inter-annual variations of species number and Shannon-Wiener diversity index $\left(H^{\prime}\right)$ subjected to 3 years of ambient deposition (control), and $\mathrm{N}$ additions of $10,20,40$, and $80 \mathrm{~kg} \mathrm{~N} \mathrm{ha}^{-1} \mathrm{year}^{-1}$. NS represented no significant differences among these five $\mathrm{N}$ addition levels
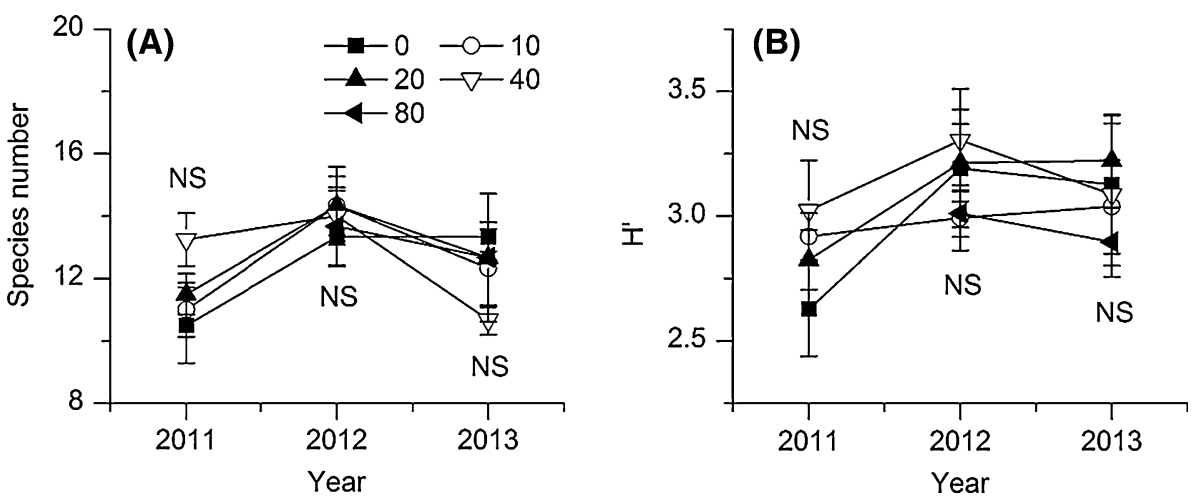
Table 1 Two-way ANOVA analysis on species richness, diversity $\left(H^{\prime}\right)$, total community cover, and aboveground biomass in an alpine meadow in Damxung County on the Tibetan Plateau subjected to
3 years of ambient deposition (control), and additions of 10, 20, 40, and $80 \mathrm{~kg} \mathrm{~N} \mathrm{ha}^{-1}$ year $^{-1}$

\begin{tabular}{|c|c|c|c|c|c|c|c|c|}
\hline & \multicolumn{2}{|c|}{ Species richness } & \multicolumn{2}{|l|}{$H^{\prime}$} & \multicolumn{2}{|c|}{ Community cover } & \multicolumn{2}{|c|}{ Aboveground biomass } \\
\hline & $F$ & $P$ & $F$ & $P$ & $F$ & $P$ & $F$ & $P$ \\
\hline Year (Y) & 7.028 & 0.003 & 5.141 & 0.012 & 3.699 & 0.036 & 22.000 & $<0.001$ \\
\hline $\mathrm{N}$ levels $(\mathrm{N})$ & 0.392 & 0.813 & 1.038 & 0.403 & 13.213 & $<0.001$ & 26.341 & $<0.001$ \\
\hline $\mathrm{Y} \times \mathrm{N}$ & 2.082 & 0.075 & 0.579 & 0.768 & 1.281 & 0.291 & 0.621 & 0.735 \\
\hline
\end{tabular}

Significance at $P<0.05$ is in bold type

Data include values collected all years from 2011 to $2013(n=4)$

Fig. 2 Community cover of aboveground vegetation in an alpine meadow in Damxung County on the Tibetan Plateau subjected to 3 years of ambient deposition (control), and $\mathrm{N}$ additions of 10, 20, 40, and $80 \mathrm{~kg} \mathrm{~N}^{-1}$ year $^{-1}$. Plant tissues were sorted into grasses, sedges, Anaphalis xylorhiza, and all other forbs. Bars represent mean \pm S.E. $(n=4)$
(A) 2011

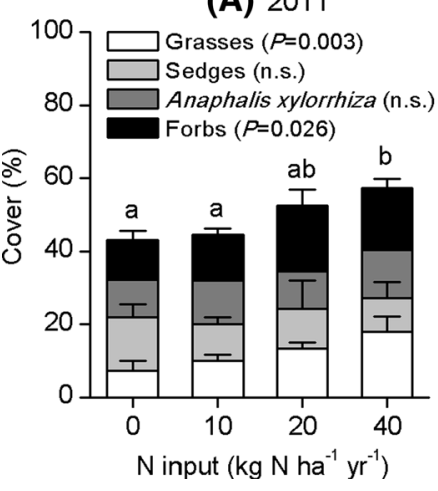

(B) 2012

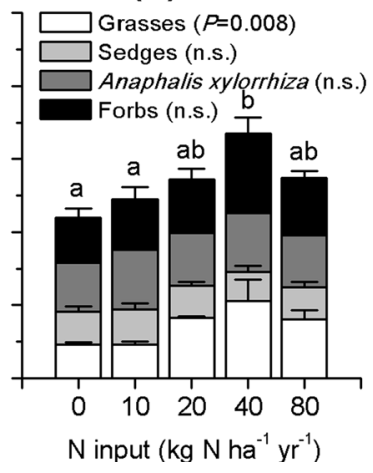

(C) 2013

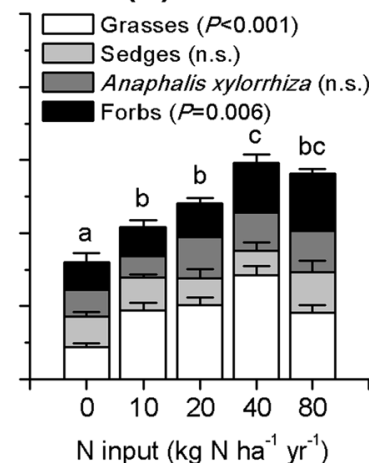

Fig. 3 The changes in cover (data in each year represented by a circle) for grasses (a), sedges (b), Anaphalis xylorhiza (c), all other forbs (d) and total cover (e) in an alpine meadow in Damxung County on the Tibetan Plateau subjected to ambient deposition (control), and additions of 10, 20, 40 and $80 \mathrm{~kg} \mathrm{~N} \mathrm{ha}^{-1}$ year $^{-1}$
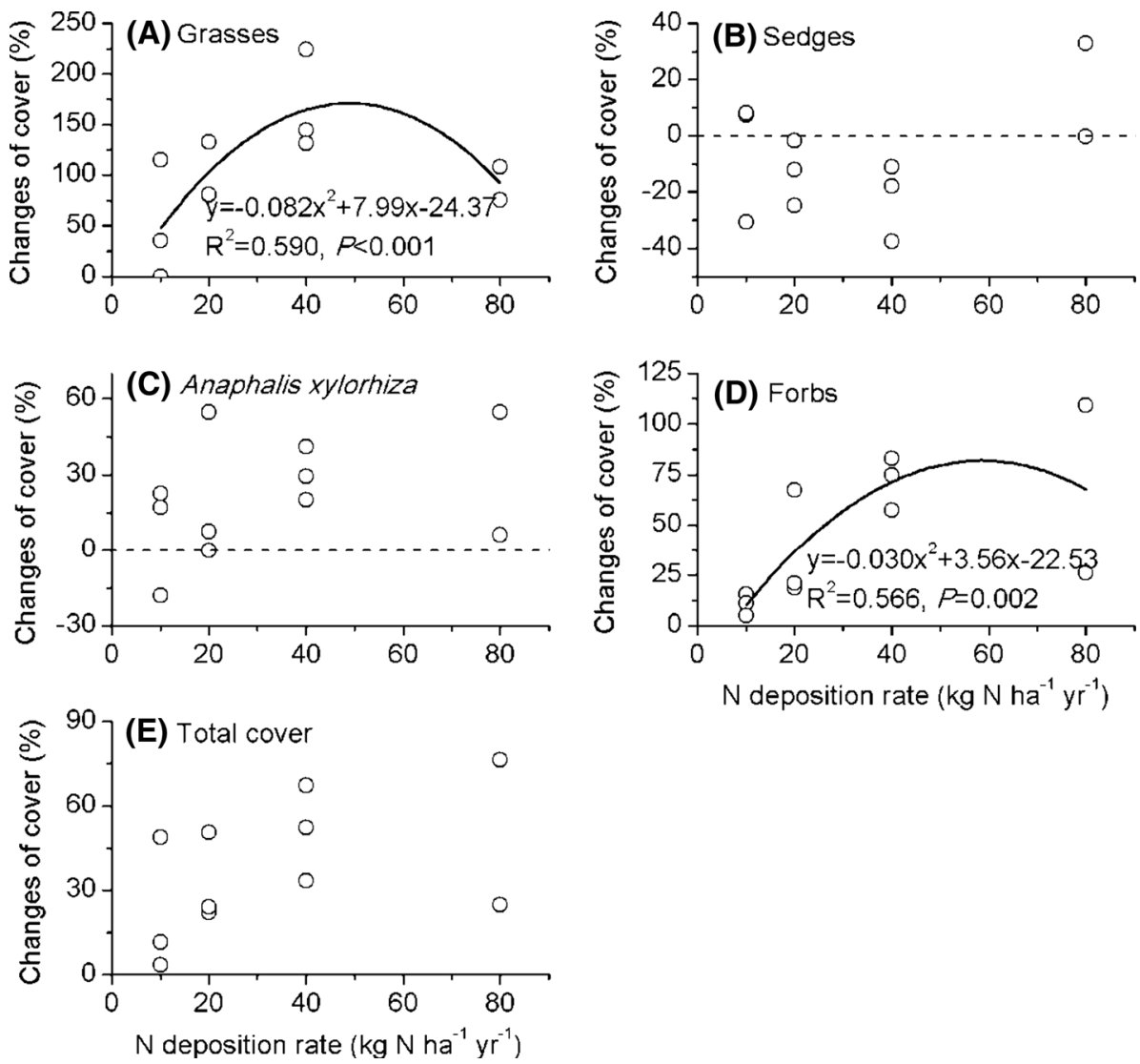
Fig. 4 Biomass of aboveground vegetation in an alpine meadow in Damxung County on the Tibetan Plateau subjected to 3 years of ambient deposition (control), and additions of $10,20,40$, and $80 \mathrm{~kg} \mathrm{~N} \mathrm{ha}^{-1}$ year $^{-1}$. Plant tissues were sorted into grasses, sedges, Anaphalis xylorhiza, and all other forbs. Bars represent mean \pm S.E. $(n=4)$
(A) 2011

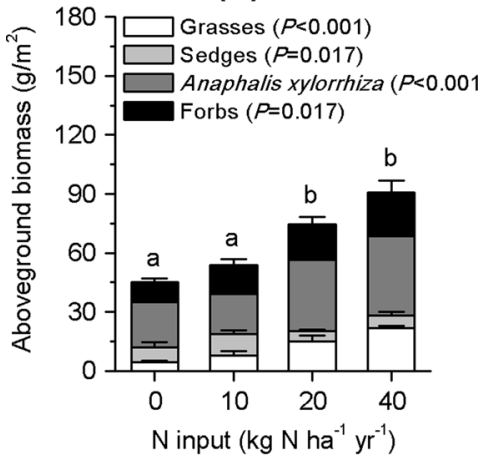

(B) 2012

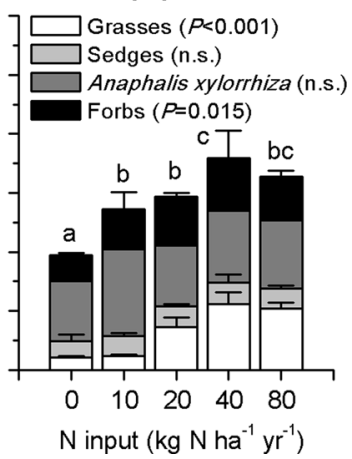

(C) 2013

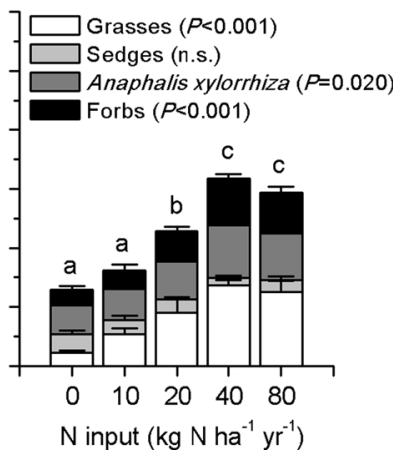

$40 \mathrm{~kg} \mathrm{~N} \mathrm{ha}^{-1}$ year $^{-1}$ (Fig. 5). Critical loads for vegetation change were $11.4,11.2,8.8$, and $9.5 \mathrm{~kg} \mathrm{~N}^{-1}$ year $^{-1}$ (including ambient deposition) for grasses, Anaphalis xylorhiza, other forbs, and total biomass, respectively.

\section{Soil Responses: Inorganic N Concentration, N Cycling Rate, and Microbial Biomass $\mathbf{C}$ and $\mathrm{N}$}

In 2011, a significant increase in the soil inorganic $\mathrm{N}$ concentration occurred with $\mathrm{N}$ addition rates equal to or greater than $10 \mathrm{~kg} \mathrm{~N}^{-1}$ year $^{-1}$, while in 2012 and 2013, this increase occurred at $\mathrm{N}$ addition rates equal to or greater than $40{\mathrm{~kg} \mathrm{~N} h \mathrm{~h}^{-1} \text { year }}^{-1}$ (Fig. $6 \mathrm{a}-\mathrm{c}$ ). The $\mathrm{NO}_{3}{ }^{-}-\mathrm{N}$ and $\mathrm{NH}_{4}{ }^{+}-\mathrm{N}$ concentrations in root layer soil increased with increasing $\mathrm{N}$ addition rates, and significant increases in $\mathrm{NO}_{3}{ }^{-}-\mathrm{N}$ and $\mathrm{NH}_{4}{ }^{+}-\mathrm{N}$ concentrations occurred between the 10 (Fig. 6a, in 2011) and $40 \mathrm{~kg} \mathrm{~N} \mathrm{ha}^{-1}$ year $^{-1}$ (Fig. 6b, c, in 2012 and 2013) treatments.

$R_{\min }$ was also affected by $\mathrm{N}$ addition. In 2011 and 2013, $\mathrm{N}$ addition rates greater than $10 \mathrm{~kg} \mathrm{~N}^{-1}$ year $^{-1}$ significantly increased $R_{\min }$ (Fig. 6a), while this pattern occurred at $\mathrm{N}$ addition rate equal to or greater than $40 \mathrm{~kg} \mathrm{~N}^{-1}$ year $^{-1}$ during 2012 (Fig. 6b, $F=90.216, P<0.001$ ). However, $R_{\min }$ returned to the control level in the
Fig. 5 The change in biomass (data in each year represented by a circle) for grasses (a), sedges (b), Anaphalis xylorhiza (c), other forbs (d), and total biomass (e) in an alpine meadow in Damxung County on the Tibetan Plateau subjected to ambient deposition (control), and additions of 10, 20, 40 and $80 \mathrm{~kg} \mathrm{~N} \mathrm{ha}^{-1}$ year $^{-1}$. The data were fit with a polynomial dose response curve
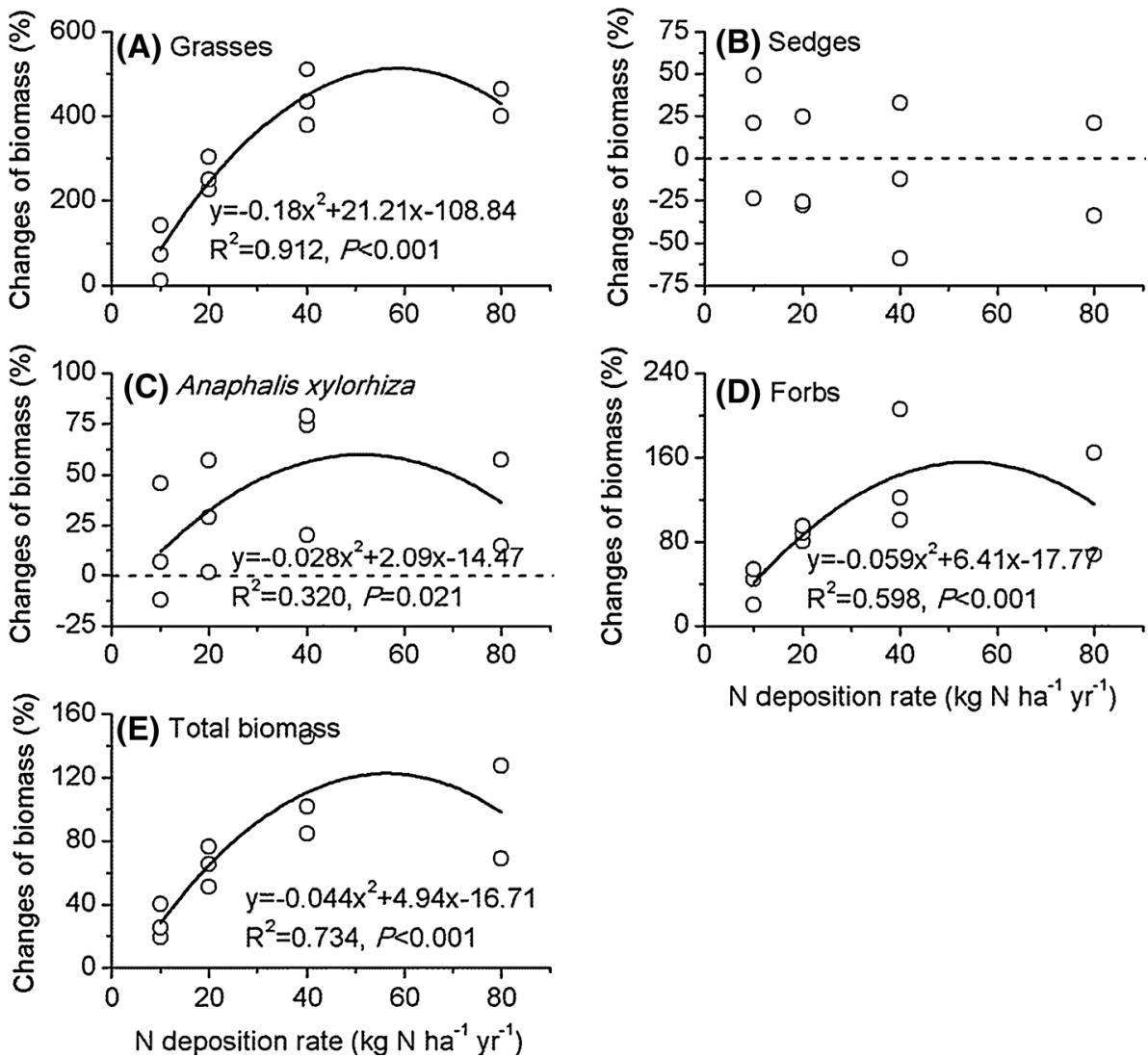
Fig. 6 Concentrations of soil inorganic $\mathrm{N}$ and net mineralization rate in an alpine meadow in Damxung County on the Tibetan Plateau subjected to 3 years of ambient deposition (control), and additions of 10 , 20,40 , and

$80 \mathrm{~kg} \mathrm{~N} \mathrm{ha}^{-1}$ year $^{-1}$. Soil inorganic $\mathrm{N}$ consisted of $\mathrm{NO}_{3}{ }^{-}$ $\mathrm{N}$ and $\mathrm{NH}_{4}{ }^{+}-\mathrm{N}$, and net mineralization rate included net nitrification $\left(r-\mathrm{NO}_{3}{ }^{-}-\mathrm{N}\right)$ and ammonification $\left(r-\mathrm{NH}_{4}{ }^{+}-\mathrm{N}\right)$ rate. Bars represent mean \pm S.E. $(n=4)$

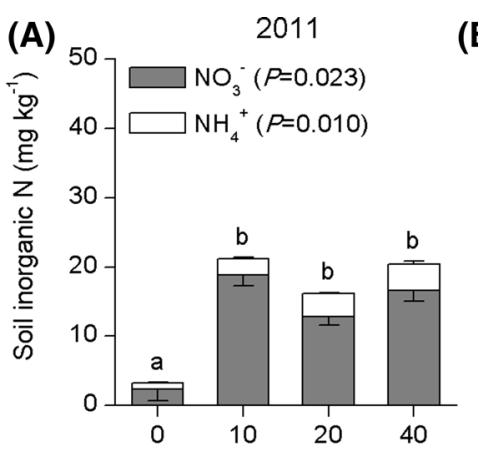

(a)

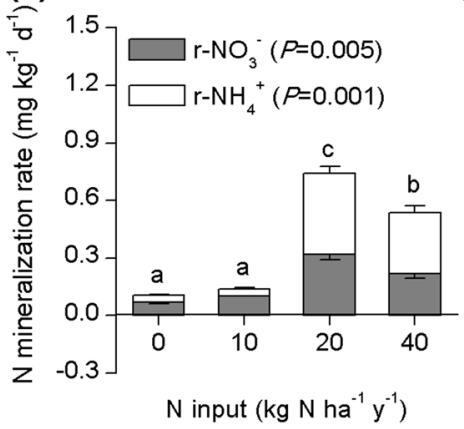

(B)

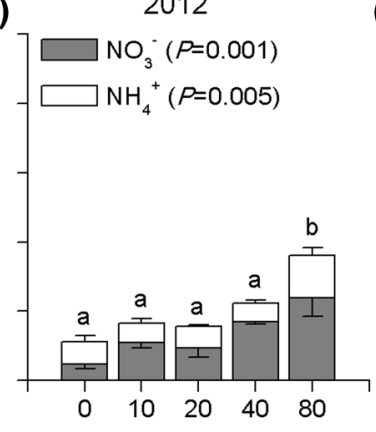

(b)

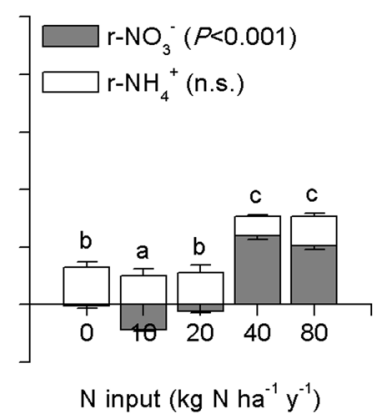

(C) 2013

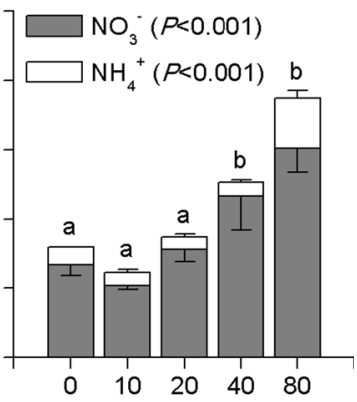

(c)

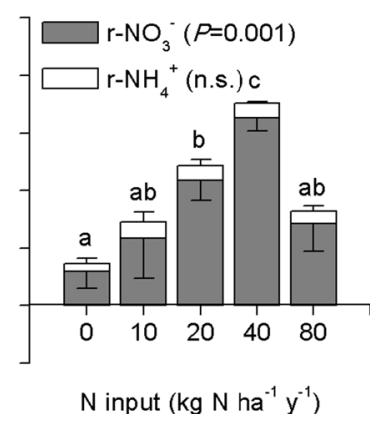

$80 \mathrm{~kg} \mathrm{~N} \mathrm{ha}^{-1}$ year $^{-1}$ addition plots (Fig. 6c). The net nitrification rate is the main component of $R_{\min }$, and it showed the same pattern as $R_{\min }$, while the net ammonification rate was only elevated at $\mathrm{N}$ addition rates greater than $10 \mathrm{~kg} \mathrm{~N} \mathrm{ha}^{-1}$ year $^{-1}$ in 2011 (Fig. 6a).

\section{Discussion}

The determination of $\mathrm{N}$ critical loads for alpine meadows is of great importance and provides an early warning before harmful effects on such ecosystems occur. Our study illustrates that the sensitive response of grasses enables the determination of $\mathrm{N}$ critical loads. The cover and biomass responses of this functional group showed a nonlinear response to increasing rates of $\mathrm{N}$ addition (Figs. 3, 5). Critical loads of $\mathrm{N}$ deposition for the alpine meadow in our study were approximately $8.8-12.7 \mathrm{~kg} \mathrm{~N} \mathrm{ha}^{-1}$ year $^{-1}$. This estimation included the ambient $\mathrm{N}$ deposition in this area (about $6 \mathrm{~kg} \mathrm{~N} \mathrm{ha}^{-1}$ year $^{-1}$ ), and is very close to the $\mathrm{N}$ critical load estimation for an alpine dry meadow, which exhibited a community response at a $\mathrm{N}$ deposition rate of $10 \mathrm{~kg} \mathrm{~N} \mathrm{ha}^{-1}$ year $^{-1}$ (Bowman et al. 2006). $\mathrm{N}$ critical load estimation in this area is also similar to the $\mathrm{N}$ critical load for ombrotrophic Sphagnum plants under increasing atmospheric $\mathrm{N}$ deposition in Europe, which exhibited changing nutritional constraints at a $\mathrm{N}$ deposition rate of $10 \mathrm{~kg} \mathrm{~N} \mathrm{ha}^{-1}$ year $^{-1}$ (Bragazza et al. 2004). This result is considerably below the critical threshold for $\mathrm{N}$-induced species loss in temperate grasslands (about $17.5 \mathrm{~kg} \mathrm{~N} \mathrm{ha}^{-1}$ year $^{-1}$; Bai et al. 2010), indicating that alpine meadow ecosystems are much more sensitive to $\mathrm{N}$ enrichment than other grassland ecosystems. Furthermore, our results also demonstrate that vegetation changes are ongoing in some parts of the Qinghai-Tibetan Plateau. Because the current N deposition rates in the eastern Qinghai-Tibetan Plateau, which range from 8.7 to $13.8 \mathrm{~kg} \mathrm{~N} \mathrm{ha}^{-1}$ year $^{-1}$ (Lü and Tian 2007), exceed this critical load, $\mathrm{N}$ deposition may have substantial effects on the functions of alpine ecosystem in this area.

\section{Plant Community Responses to N Addition}

In this study, the diversity and richness of vascular plant species did not exhibit statistically significant responses to increasing $\mathrm{N}$ addition, which is in contrast to most previous studies that showed a loss of plant species richness in response to $\mathrm{N}$ addition (Bai et al. 2004; Chen et al. 2013; Fang et al. 2012). In these studies, nitrophilic species may become dominant, and rare species may be excluded by competition within the plant community for nutrient resources (Suding et al. 2005). Moreover, competition for light may be another important reason for the disappearance of some species, because those species at the top of the canopy and/or those with a fast growth rate have easy access to light (Bowman et al. 1993; Hautier et al. 2009; Suding et al. 2005). However, with relatively lower species numbers and a low-density plant community, light 
competition resulting from $\mathrm{N}$ input is less severe in the alpine meadow in our study compared with other ecosystems. Additionally, although the diversity and richness of vascular plant species did not exhibit statistically significant responses to increasing rates of $\mathrm{N}$ addition, they changed with years. The insignificant change in species composition may be partly due to the relatively short experimental time, as the results in this study were from the second to the fourth experimental years.

Generally, biological responses to $\mathrm{N}$ deposition are nonlinear, and $\mathrm{N}$ saturation is defined as the critical threshold point above which ecosystem functions may shift in unpredictable ways (Wei et al. 2013). N saturation occurs when supplies of ammonium and nitrate are in excess of the total combined plant and microbial demand (Aber et al. 1989, 1998). In this study, plant community cover and biomass displayed unimodal patterns in response to $\mathrm{N}$ addition levels, with peak values occurring at the $50 \mathrm{~kg} \mathrm{~N} \mathrm{ha}^{-1}$ year $^{-1}$ addition rate (Figs. 2, 4), which indicates that the $50 \mathrm{~kg} \mathrm{~N}^{-1}$ year $^{-1}$ addition rate is the $\mathrm{N}$ saturation threshold for the plant community of this alpine meadow ecosystem. This result is of great importance for rangeland management, as fertilization has become a frequently used measure for the restoration of degraded rangelands (Bai et al. 2010; Conant et al. 2001; Schellberg et al. 1999). From a management perspective, $N$ addition levels greater than $50 \mathrm{~kg} \mathrm{~N}^{-1}$ year $^{-1}$ do not yield more forages but require more fertilization input, resulting in insufficient economic benefits. Additionally, the results from another long-term fertilization experiment in this region showed that plant community cover and aboveground biomass in $100 \mathrm{~kg} \mathrm{~N} \mathrm{ha}^{-1}$ year $^{-1}$ addition plots were lower than those under a $50 \mathrm{~kg} \mathrm{~N} \mathrm{ha}^{-1}$ year $^{-1}$ addition treatment in the sixth year of $\mathrm{N}$ addition treatment (Zong et al. 2014a, b). In addition, excessive $\mathrm{N}$ input will also elicit a series of environmental problems.

The responses of plant community cover and biomass to $\mathrm{N}$ input are mediated in part by changes in plant growth (Bowman 1994; Bowman et al. 1993; Theodose and Bowman 1997). In our study, the most pronounced functional group that exhibited cover and biomass increases was grasses, which is similar to the results of other nutrient addition experiments in alpine meadows (Bowman 1994; Theodose and Bowman 1997). Generally, rhizomatous grasses are better adapted to high $\mathrm{N}$ levels (Bai et al. 2010). As faster-growing and tall species, grasses are in the upper part of the community canopy and outcompete other species for light (Hautier et al. 2009). Furthermore, with their fibrous root systems, grasses have greater abilities to compete for soil water and nutrient resources (Yang et al. 2014). Recent studies reported that the soil organic $\mathrm{N}$ and nitrate absorption capacities of the grasses Poa pratensis and Stipa aliena are greater than those of other species in an alpine community, as shown by an in situ ${ }^{15} \mathrm{~N}$ isotope labeling technique (Wang et al. 2012b). As palatable forage grasses, the increase in grasses is beneficial to the recovery of degraded rangelands, as well as livestock husbandry. The cover of sedges and the most dominant species, Anaphalis xylorhiza, in the meadow community did not significantly respond to $\mathrm{N}$ enrichment, while other forbs increased in the second and fourth experimental years. Differences in growth form and physiology principally account for the differential responses of plants to $\mathrm{N}$ enrichment (Aerts and Berendse 1988; Bowman and Conant 1994; Chapin 1980; Theodose and Bowman 1997). Therefore, when $\mathrm{N}$ deposition reaches or exceeds the saturation threshold, the structure of grassland ecosystems can be altered by shifts in plant functional group composition (Bai et al. 2010; Clark and Tilman 2008).

\section{Soil Responses to N Enrichment}

Consistent with previous studies (Bowman et al. 2012; Contosta et al. 2011; Wei et al. 2013), external N input increased soil inorganic $\mathrm{N}$ concentrations, but the effects varied with years (Fig. 6). This phenomenon has been observed in previous studies (Aber et al. 1993; Magill et al. 1996). Relative to $\mathrm{NH}_{4}{ }^{+}-\mathrm{N}$, the increase in the $\mathrm{NO}_{3}{ }^{-}-\mathrm{N}$ concentration was more pronounced in response to $\mathrm{N}$ input (Fig. 6), possibly resulting in the potential risk of nitrate leaching from the soil, as well as detrimental effects on the environment. Additionally, increases in soil $\mathrm{NO}_{3}{ }^{-}-\mathrm{N}$ leaching can initiate acidification, as soil cations are removed from cation-exchange sites and replaced by protons (Binkley and Richter 1987; van Breemen et al. 1983). Increases in $\mathrm{NH}_{4}{ }^{+}-\mathrm{N}$ can enhance nitrification rates, which will also acidify soils (Bowman et al. 2012). Recent studies reported that soil $\mathrm{pH}$ in the surface layer declined by approximately 0.61 units in an alpine meadow due to atmospheric $\mathrm{N}$ deposition during the last two decades (Yang et al. 2012). Sustained, long-term soil acidification could induce the release of mobile forms of $\mathrm{Al}^{3+}$, which are toxic to vegetation in grassland ecosystems (Bowman et al. 2008).

Unlike the increase in soil inorganic $\mathrm{N}$, the effects of external $\mathrm{N}$ input on soil net mineralization and nitrification rates varied at $\mathrm{N}$ addition levels between 20 and $40 \mathrm{~kg} \mathrm{~N} \mathrm{ha}^{-1}$ year $^{-1}$ over the experimental years. In the fourth year, the net mineralization rate under the $80 \mathrm{~kg} \mathrm{~N} \mathrm{ha}^{-1}$ year $^{-1}$ addition treatment returned to the control level (Fig. 6), further suggesting that $\mathrm{N}$ addition levels in excess of $80 \mathrm{~kg} \mathrm{~N} \mathrm{ha}^{-1}$ year $^{-1}$ may lead to $\mathrm{N}$ saturation. Likewise, studies of forest ecosystems reported that $\mathrm{N}$ addition initially increased $\mathrm{N}$ mineralization, but that elevated rates of $\mathrm{N}$ cycling either returned to original levels (Aber et al. 1993; Magill et al. 1996) or even 
declined after a few months or years of fertilization (McNulty et al. 1996), as the external N supply exceeds plant and soil microbial demand for N (Gilliam et al. 2005). This was confirmed by our own results, which suggests that changes in soil mineralization and nitrification rates in alpine meadows could be comparable to those of forest ecosystems, and that they could serve as early signals of $\mathrm{N}$ saturation.

Unexpectedly, SMC only responded to $\mathrm{N}$ addition in 2013 (Fig. S1). Some other studies also found similar results. For example, there is evidence that in boreal ecosystems, fungal and microbial biomass does not always respond to $\mathrm{N}$ addition (Allison et al. 2008; Boxman et al. 1998; Brenner et al. 2005; Ramirez et al. 2012). Thus, SMC in alpine soils may not be as sensitive to $\mathrm{N}$ addition compared with other soil parameters. Furthermore, a global meta-analysis revealed that $\mathrm{N}$ addition inhibited microbial activity, as indicated by a reduction in SMC (Janssens et al. 2010; Liu and Greaver 2010; Treseder 2008), and the negative impacts were primarily significant for $\mathrm{NH}_{4}{ }^{+}-\mathrm{N}$ and $\mathrm{NH}_{4} \mathrm{NO}_{3}$ inputs (Liu and Greaver 2010). This reduction was attributed to the following mechanisms: (i) the toxicity effects caused by $\mathrm{N}$ enrichment, such as increasing osmotic pressure, soil acidity, and aluminum toxicity, offset the positive effects of increasing the labile C supply (Liu and Greaver 2010), and (ii) the limited resources for microbial communities shifted from $\mathrm{C}$ to water, phosphorus, or other resources (Liu and Greaver 2010; Zhang et al. 2013). N addition tended to increase SMN, resulting in a decrease in the soil microbial C/N ratio in 2013 (Fig. S1).

\section{Ecosystem Implications of N Saturation Thresholds}

Because of the location and high latitude of the QinghaiTibetan Plateau, its ecosystems and natural environment are inherently fragile and unstable, making them especially sensitive to global climatic changes. Moreover, because of their thin soils and low biological buffering capacity, alpine ecosystems are particularly susceptible to $\mathrm{N}$ deposition (Bowman et al. 2006; Williams and Tonnessen 2000; Williams et al. 1996). If the thresholds of $\mathrm{N}$ inputs are reached and/or exceeded, national water resources and ecological security will be endangered by nitrate leaching and a reduction in species diversity. To date, no similar study has been conducted in this region. As the plant functional groups and soil properties showed nonlinear responses to long-term and multiple-level $\mathrm{N}$ inputs, we evaluated the $\mathrm{N}$ critical loads for vegetation cover and biomass changes in an alpine meadow on the QinghaiTibetan Plateau. The $\mathrm{N}$ critical loads identified in this study could be used to mitigate adverse environmental effects before further environmental deterioration occurs under future increasing rates of atmospheric $\mathrm{N}$ deposition.

In addition, our results indicated that the $50 \mathrm{~kg} \mathrm{~N} \mathrm{ha}^{-1}$ year $^{-1}$ addition rate is the $\mathrm{N}$ saturation threshold for the plant community of this alpine meadow ecosystem. This result is of great importance for rangeland management, as $\mathrm{N}$ addition level greater than $50 \mathrm{~kg} \mathrm{~N} \mathrm{ha}^{-1}$ year $^{-1}$ do not yield more forages but require more fertilization input, resulting in insufficient economic benefits. This result could also provide useful scientific guidelines for the management of alpine ecosystems on the Qinghai-Tibet Plateau.

\section{Conclusions}

To our knowledge, this is the first study to evaluate the $\mathrm{N}$ critical loads for plant and soil changes of an alpine meadow on the Qinghai-Tibetan Plateau. The current N deposition rate in the eastern Qinghai-Tibetan Plateau ranges from 8.7 to $13.8 \mathrm{~kg} \mathrm{~N} \mathrm{ha}^{-1}$ year $^{-1}$ (Lü and Tian 2007), which nearly exceeds the $\mathrm{N}$ critical loads for plant community functional group change. We speculate that community composition changes are probably ongoing in some parts of the Qinghai-Tibetan Plateau. However, notable changes in soil characteristics occurred at $\mathrm{N}$ addition rates equal to or greater than $20 \mathrm{~kg} \mathrm{~N} \mathrm{ha}^{-1}$ year $^{-1}$ (not including the ambient deposition rate). These findings provide evidence that support the conclusions of Bowman et al. (2006) and Bai et al. (2010), who showed that the vegetation compositions of grassland ecosystems are much more sensitive than soil to external N inputs. By 2050, the $\mathrm{N}$ deposition rate on the Qinghai-Tibetan Plateau is projected to increase to $40 \mathrm{~kg} \mathrm{~N} \mathrm{ha}^{-1}$ year $^{-1}$ (Galloway et al. 2004), which is equal to the estimation of the $\mathrm{N}$ saturation threshold for alpine meadow community cover and plant production in this region. If $\mathrm{N}$ deposition is greater than the threshold, the biotic and abiotic demands for $\mathrm{N}$ deposition will be exceeded, thereby leading to further increases in soil $\mathrm{NO}_{3}{ }^{-}-\mathrm{N}$ leaching and acidification, which may eventually result in detrimental and irreversible impacts on the stability and sustainability of alpine ecosystems.

Acknowledgments We thank Doctor Bing Song for her valuable comments on the improvement of the manuscript. This work was jointly supported by the National Natural Science Foundation of China (No. 41271067), the Strategic Priority Research Program of the Chinese Academy of Sciences "Climate Change: Carbon Budget and Relevant Issues" (Grant No. XDA05060700), the Excellent Young Scientists Grant from the Institute of Geographic Sciences and Natural Resources Research, CAS (2011RC101), and the Innovation Project Grant from the Institute of Geographic Sciences and Natural Resources Research, CAS (201003012). 


\section{References}

Aber JD, Nadelhoffer KJ, Steudler P, Melillo JM (1989) Nitrogen saturation in northern forest ecosystems. Bioscience 39:378-386

Aber JD, Magill Alison, Boone Richard, Melillo JM, Steudler P (1993) Plant and soil responses to chronic nitrogen additions at the Harvard Forest, Massachusetts. Ecol Appl 3:156-166

Aber J, McDowell W, Nadelhoffer K, Magill A, Berntson G, Kamakea M, McNulty S, Currie W, Rustad L, Fernandez I (1998) Nitrogen saturation in temperate forest ecosystems: hypotheses revisited. Bioscience 48:921-934

Aerts R, Berendse F (1988) The effect of increased nutrient availability on vegetation dynamics in wet heathlands. Vegetatio 76:63-69

Allison SD, Czimczik CI, Treseder KK (2008) Microbial activity and soil respiration under nitrogen addition in Alaskan boreal forest. Global Change Biol 14:1156-1168

Bai Y, Han X, Wu J, Chen Z, Li L (2004) Ecosystem stability and compensatory effects in the Inner Mongolia grassland. Nature 431:181-184

Bai Y, Wu J, Clark CM, Naeem S, Pan Q, Huang J, Zhang L, Han X (2010) Tradeoffs and thresholds in the effects of nitrogen addition on biodiversity and ecosystem functioning: evidence from inner Mongolia Grasslands. Global Change Biol 16:358-372

Binkley D, Richter D (1987) Nutrient cycles and $\mathrm{H}^{+}$budgets of forest ecosystems. Adv Ecol Res 16:1-51

Bobbink R, Roelofs JGM (1995) Nitrogen critical loads for natural and semi-natural ecosystems: the empirical approach. Water Air Soil Pollut 85:2413-2418

Bobbink R, Hornung M, Roelofs JG (1998) The effects of air-borne nitrogen pollutants on species diversity in natural and seminatural European vegetation. J Ecol 86:717-738

Bobbink R, Hicks K, Galloway J, Spranger T, Alkemade R, Ashmore M, Bustamante M, Cinderby S, Davidson E, Dentener F, Emmett B, Erisman JW, Fenn M, Gilliam F, Nordin A, Pardo L, De Vries W (2010) Global assessment of nitrogen deposition effects on terrestrial plant diversity: a synthesis. Ecol Appl 20:30-59

Bowman WD (1994) Accumulation and use of nitrogen and phosphorus following fertilization in two alpine tundra communities. Oikos 70:261-270

Bowman WD, Conant RT (1994) Shoot growth dynamics and photosynthetic response to increased nitrogen availability in the alpine willow Salix glauca. Oecologia 97:93-99

Bowman WD, Theodose TA, Schardt JC, Conant RT (1993) Constraints of nutrient availability on primary production in two alpine tundra communities. Ecology 74:2085-2097

Bowman WD, Gartner JR, Holland K, Wiedermann M (2006) Nitrogen critical loads for alpine vegetation and terrestrial ecosystem response: are we there yet? Ecol Appl 16:1183-1193

Bowman WD, Cleveland CC, Halada L, Hresko J, Baron JS (2008) Negative impact of nitrogen deposition on soil buffering capacity. Nat Geosci 1:767-770

Bowman WD, Murgel J, Blett T, Porter E (2012) Nitrogen critical loads for alpine vegetation and soils in Rocky Mountain National Park. J Environ Manag 103:165-171

Boxman AW, Blanck K, Brandrud TE, Emmett BA, Gundersen P, Hogervorst RF, Kjonaas OJ, Persson H, Timmermann V (1998) Vegetation and soil biota response to experimentally-changed nitrogen inputs in coniferous forest ecosystems of the NITREX project. For Ecol Manag 101:65-79

Bragazza L, Tahvanainen T, Kutnar L, Rydin H, Limpens J, Hajek M, Grosvernier P, Hajek T, Hajkova P, Hansen I, Iacumin P, Gerdol R (2004) Nutritional constraints in ombrotrophic Sphagnum plants under increasing atmospheric nitrogen deposition in Europe. New Phytol 163:609-616
Brenner R, Boone RD, Ruess RW (2005) Nitrogen additions to pristine, high-latitude, forest ecosystems: consequences for soil nitrogen transformations and retention in mid and late succession. Biogeochemistry 72:257-282

Chapin FS (1980) The mineral nutrition of wild plants. Annu Rev Ecol Syst 11:233-260

Chen D, Lan Z, Bai X, Grace JB, Bai Y (2013) Evidence that acidification-induced declines in plant diversity and productivity are mediated by changes in below-ground communities and soil properties in a semi-arid steppe. J Ecol 101:1322-1334

Clark CM, Tilman D (2008) Loss of plant species after chronic lowlevel nitrogen deposition to prairie grasslands. Nature 451:712-715

Conant RT, Paustian K, Elliott ET (2001) Grassland management and conversion into grassland: effects on soil carbon. Ecol Appl $11: 343-355$

Contosta AR, Frey SD, Cooper AB (2011) Seasonal dynamics of soil respiration and $\mathrm{N}$ mineralization in chronically warmed and fertilized soils. Ecosphere 2: Article 36

Fang Y, Xun F, Bai W, Zhang W, Li L (2012) Long-term nitrogen addition leads to loss of species richness due to litter accumulation and soil acidification in a temperate steppe. PLoS One 7:e47369

Fu G, Shen Z, Zhang X, Zhou Y, Zhang Y (2012) Response of microbial biomass to grazing in an alpine meadow along an elevation gradient on the Tibetan Plateau. Eur J Soil Biol 52:27-29

Galloway JN, Dentener FJ, Capone DG, Boyer EW, Howarth RW, Seitzinger SP, Asner GP, Cleveland CC, Green PA, Holland EA, Karl DM, Michaels AF, Porter JH, Townsend AR, Vöosmarty CJ (2004) Nitrogen cycles: past, present, and future. Biogeochemistry 70:153-226

Galloway JN, Townsend AR, Erisman JW, Bekunda M, Cai Z, Freney JR, Martinelli LA, Seitzinger SP, Sutton MA (2008) Transformation of the nitrogen cycle: recent trends, questions, and potential solutions. Science 320:889-892

Gilliam FS, Lyttle NL, Thomas A, Adams MB (2005) Soil variability along a nitrogen mineralization and nitrification gradient in a nitrogen-saturated hardwood forest. Soil Sci Soc Am J 69:247-256

Guo JH, Liu XJ, Zhang Y, Shen JL, Han WX, Zhang WF, Christie P, Goulding KWT, Vitousek PM, Zhang FS (2010) Significant acidification in major Chinese croplands. Science 327:1008-1010

Hautier Y, Niklaus PA, Hector A (2009) Competition for light causes plant biodiversity loss after eutrophication. Science 324:636-638

Janssens IA, Dieleman W, Luyssaert S, Subke JA, Reichstein M, Ceulemans R, Ciais P, Dolman AJ, Grace J, Matteucci G, Papale D, Piao SL, Schulze ED, Tang J, Law BE (2010) Reduction of forest soil respiration in response to nitrogen deposition. Nat Geosci 3:315-322

Jiang J, Zong N, Song M, Shi P, Ma W, Fu G, Shen Z, Zhang X, Ouyang H (2013) Responses of ecosystem respiration and its components to fertilization in an alpine meadow on the Tibetan Plateau. Eur J Soil Biol 56:101-106

LeBauer DS, Treseder KK (2008) Nitrogen limitation of net primary productivity in terrestrial ecosystems is globally distributed. Ecology 89:371-379

Lieb AM, Darrouzet-Nardi A, Bowman WD (2011) Nitrogen deposition decreases acid buffering capacity of alpine soils in the southern Rocky Mountains. Geoderma 164:220-224

Lin X, Zhang Z, Wang S, Hu Y, Xu G, Luo C, Chang X, Duan J, Lin Q, Xu B, Wang Y, Zhao X, Xie Z (2011) Response of ecosystem respiration to warming and grazing during the growing seasons in the alpine meadow on the Tibetan plateau. Agric For Meteorol 151:792-802 
Liu L, Greaver TL (2010) A global perspective on belowground carbon dynamics under nitrogen enrichment. Ecol Lett 13:819-828

Lovett G, Goodale C (2011) A new conceptual model of nitrogen saturation based experimental nitrogen addition to an oak forest. Ecosystems 14:615-631

Lü C, Tian H (2007) Spatial and temporal patterns of nitrogen deposition in China: synthesis of observational data. J Geophys Res 112:D22S05

Lu M, Yang Y, Luo Y, Fang C, Zhou X, Chen J, Yang X, Li B (2011) Responses of ecosystem nitrogen cycle to nitrogen addition: a meta-analysis. New Phytol 189:1040-1050

Magill AH, Downs MR, Nadelhoffer KJ, Hallett RA, Aber JD (1996) Forest ecosystem response to four years of chronic nitrate and sulfate additions at Bear Brooks Watershed, Maine, USA. For Ecol Manag 84:29-37

Matson P, Lohse KA, Hall SJ (2002) The globalization of nitrogen deposition: consequences for terrestrial ecosystems. Ambio 31:113-119

McNulty SG, Aber JD, Newman SD (1996) Nitrogen saturation in a high elevation New England spruce-fir stand. For Ecol Manag 84:109-121

Pardo LH, Fenn ME, Goodale CL, Geiser LH, Driscoll CT, Allen EB, Baron JS, Bobbink R, Bowman WD, Clark CM, Emmett B, Gilliam FS, Greaver TL, Hall SJ, Lilleskov EA, Liu L, Lynch JA, Nadelhoffer KJ, Perakis SS, Robin-Abbott MJ, Stoddard JL, Weathers KC, Dennis RL (2011) Effects of nitrogen deposition and empirical nitrogen critical loads for ecoregions of the United States. Ecol Appl 21:3049-3082

Phoenix GK, Emmett BA, Britton AJ, Caporn SJM, Dise NB, Helliwell R, Jones L, Leake JR, Leith ID, Sheppard LJ, Sowerby A, Pilkington MG, Rowe EC, Ashmore MR, Power SA (2012) Impacts of atmospheric nitrogen deposition: responses of multiple plant and soil parameters across contrasting ecosystems in longterm field experiments. Global Change Biol 18:1197-1215

Porter E, Blett T, Potter DU, Huber C (2005) Protecting resources on federal lands: implications of critical loads for atmospheric deposition of nitrogen and sulfur. Bioscience 55:603-612

Ramirez KS, Craine JM, Fierer N (2012) Consistent effects of nitrogen amendments on soil microbial communities and processes across biomes. Global Change Biol 18:1918-1927

Sala OE, Chapin FS III, Armesto JJ, Berlow E, Bloomfield J, Dirzo R, Huber-Sanwald E, Huenneke LF, Jackson RB, Kinzig A, Leemans R, Lodge DM, Mooney HA, Oesterheld MN, Poff NL, Sykes MT, Walker BH, Walker M, Wall DH (2000) Global biodiversity scenarios for the year 2100. Science 287:1770-1774

Schellberg J, Moseler BM, Kuhbauch W, Rademacher IF (1999) Long-term effects of fertilizer on soil nutrient concentration, yield, forage quality and floristic composition of a hay meadow in the Eifel mountains, Germany. Grass Forage Sci 54:195-207

Stevens CJ, Dise NB, Mountford JO, Gowing DJ (2004) Impact of nitrogen deposition on the species richness of grasslands. Science 303:1876-1879

Stevens CJ, Dupre C, Dorland E, Gaudnik C, Gowing DJG, Bleeker A, Diekmann M, Alard D, Bobbink R, Fowler D, Corcket E, Mountford JO, Vandvik V, Aarrestad PA, Muller S, Dise NB (2010) Nitrogen deposition threatens species richness of grasslands across Europe. Environ Pollut 158:2940-2945

Suding KN, Collins SL, Gough L, Clark C, Cleland EE, Gross KL, Milchunas DG, Pennings S (2005) Functional- and abundancebased mechanisms explain diversity loss due to $\mathrm{N}$ fertilization. PNAS 102:4387-4392

Sun H, Zheng D, Yao T, Zhang Y (2012) Protection and construction of the national ecological security shelter zone on Tibetan Plateau. Acta Geograph Sinica 67:3-12 (Chinese with English abstract)
Tang MC, Li CQ, Zhang J (1986) The climate change of QinghaiXizang plateau and its neighborhood. Plateau Meteorol 631:39-49

Theodose TA, Bowman WD (1997) Nutrient availability, plant abundance, and species diversity in two alpine tundra communities. Ecology 78:1861-1872

Tilman D, Wedin D, Knops J (1996) Productivity and sustainability influenced by biodiversity in grassland ecosystems. Nature 379:718-720

Tilman D, Reich PB, Knops JMH (2006) Biodiversity and ecosystem stability in a decade-long grassland experiment. Nature 441:629-632

Treseder KK (2008) Nitrogen additions and microbial biomass: a meta-analysis of ecosystem studies. Ecol Lett 11:1111-1120

van Breemen N, Mulder J, Driscoll CT (1983) Acidification and alkalinization of soils. Plant Soil 75:283-308

Vance ED, Brookes PC, Jenkinson DS (1987) An extraction method for measuring soil microbial biomass C. Soil Biol Biochem 19:703-707

Wang S, Duan J, Xu G, Wang Y, Zhang Z, Rui Y, Luo C, Xu B, Zhu X, Chang X, Cui X, Niu H, Zhao X, Wang W (2012a) Effects of warming and grazing on soil $\mathrm{N}$ availability, species composition, and ANPP in an alpine meadow. Ecology 93:2365-2376

Wang W, Ma Y, Xu J, Wang H, Zhu J, Zhou H (2012b) The uptake diversity of soil nitrogen nutrients by main plant species in Kobresia humilis alpine meadow on the Qinghai-Tibet Plateau. Sci China Ser D 42:1264-1272

Wei C, Bai E, Yu Q, Lü X, Li Q, Xia J, Kardol P, Liang W, Wang Z, Han X (2013) Nitrogen deposition weakens plant-microbe interactions in grassland ecosystems. Global Change Biol 19:3688-3697

Williams MW, Tonnessen KA (2000) Critical loads for inorganic nitrogen deposition in the Colorado Front Range, USA. Ecol Appl 10:1648-1665

Williams MW, Baron JS, Caine N, Sommerfeld R, Sanford R (1996) Nitrogen saturation in the Rocky Mountains. Environ Sci Technol 30:640-646

Xia JY, Wan SQ (2008) Global response patterns of terrestrial plant species to nitrogen addition. New Phytol 179:428-439

Xu Z, Hu R, Xiong P, Wan C, Cao G, Liu Q (2010) Initial soil responses to experimental warming in two contrasting forest ecosystems, Eastern Tibetan Plateau, China: nutrient availabilities, microbial properties and enzyme activities. Appl Soil Ecol 46:291-299

Yang Y, Ji C, Ma W, Wang S, Wang S, Han W, Mohammat A, Robinson D, Smith P (2012) Significant soil acidification across northern China's grasslands during 1980s-2000s. Global Change Biol 18:2292-2300

Yang X, Ren F, Zhou H, He J (2014) Responses of plant community biomass to nitrogen and phosphorus additions in an alpine meadow on the Qinghai-Xizang Plateau. Chin J Plant Ecol 38:159-166

Zhang N, Guo R, Song P, Guo J, Gao Y (2013) Effects of warming and nitrogen deposition on the coupling mechanism between soil nitrogen and phosphorus in Songnen Meadow Steppe, northeastern China. Soil Biol Biochem 65:96-104

Zheng D, Zhang R, Yang Q (1979) On the natural zonation in the Qinghai-Xizang Plateau. Acta Geogr Sin 34:1-11 (Chinese with English abstract)

Zong N, Shi P, Jiang J, Song M, Xiong D, Ma W, Fu G, Zhang X, Shen $\mathrm{Z}$ (2013) Responses of ecosystem $\mathrm{CO}_{2}$ fluxes to shortterm experimental warming and nitrogen enrichment in an alpine meadow, northern Tibet Plateau. Sci World J: Article ID 415318

Zong N, Song M, Shi P, Jiang J, Zhang X, Shen Z (2014a) Timing patterns of nitrogen application alter plant production and $\mathrm{CO}_{2}$ 
efflux in an alpine meadow on the Tibetan Plateau, China. Pedobiologia 57:263-269

Zong N, Shi P, Niu B, Jiang J, Song M, Zhang X, He Y (2014b) Effects of nitrogen and phosphorous fertilization on community structure and productivity of degraded alpine meadows in northern Tibet, China. Chin J Appl Ecol 25:3458-3468 (Chinese with English abstract) 